\title{
Two new species of the subfamily Erigoninae from the Caucasus (Aranei: Linyphiidae)
}

\author{
Ава новых вида пауков подсемейства Erigoninae с Кавказа \\ (Aranei: Linyphiidae)
}

\author{
A.V. Tanasevitch ${ }^{1}$, A.V. Ponomarev ${ }^{2}$, Yu.A. Chumachenko ${ }^{3}$ \\ А.В. Танасевич ${ }^{1}$, А.В. Пономарёв ${ }^{2}$ Ю.А. Чумаченко ${ }^{3}$

\footnotetext{
${ }^{1}$ Institute of Ecology and Evolution, Russian Academy of Sciences, Leninsky prospekt, 33, Moscow 119071, Russia. E-mail: tanasevitch@gmail.com.

Институт проблем экологии и эволюции РАН, Ленинский проспект, 33, Москва 119071, Россия.

2 Institute of Arid Zones, Southern Scientific Centre, Russian Academy of Sciences, Chekhov str., 41, Rostov-on-Don 344006, Russia. Email: ponomarev1952@mail.ru.

Институт аридных зон, Южный научный центр РАН, пр. Чехова, 41, Ростов-на-Дону 344006, Россия.

${ }_{3}^{3}$ Caucasian State Biosphere Nature Reserve, Sovetskaya str., 187, Maikop 385000, Russia. E-mail: ychumachenko73@mail.ru.

Кавказский государственный природный биосферный заповедник, ул. Советская, 187, Майкоп 385000, Россия.
}

KEY WORDS: spiders, Asthenargus, Maculoncus, Russia, Adygea, Georgia, new species.

КЛЮЧЕВЫЕ СЛОВА: пауки, Asthenargus, Maculoncus, Россия, Адыгея, Грузия, новые виды.

ABSTRACT. Two new species of the subfamily Erigoninae are described from the Caucasus: Asthenargus adygeicus sp.n. (Adygea Republic, Russia) and Maculoncus (?) obscurus sp.n. (Adygea Republic, Russia; Georgia). A. adygeicus sp.n. seems to be most similar to the Caucasian A. caucasicus Tanasevitch, 1987, but is distinguished by the absence of a mastidion in the male chelicerae, as well as by a few details of genitalic structure in both sexes. Since the taxonomic position of $M$. (?) obscurus sp.n., described from males alone, remains unclear, it is provisionally assigned to the genus Maculoncus Wunderlich, 1995.

РЕЗЮМЕ. Два новых вида подсемейства Erigoninae описаны с Кавказа: Asthenargus adygeicus sp.n. из Адыгеи, Россия и Maculoncus (?) obscurus sp.n. из Адыгеи и Грузии. A. adygeicus sp.n. наиболее близок к кавказскому A. caucasicus Tanasevitch, 1987, от которого отличается отсутствием мастидиона на хелицерах самца, а также деталями строения гениталий обоих полов. Таксономическое положение $M$. (?) obscurus sp.n., описанного по самцам, не ясно; вид помещён в род Maculoncus Wunderlich, 1995 условно.

\section{Introduction}

This paper continues our series of publications devoted to descriptions of new linyphiid species from the Caucasus (see Tanasevitch et al., 2015; Tanasevitch, Ponomarev, 2015; Tanasevitch et al., 2016). The current contribution describes two new species of Erigoninae from the Republic of Adygea, Russia, partly also from Georgia.

\section{Material and methods}

The type specimens are shared between the collections of the Zoological Museum of the Moscow State University, Moscow, Russia (ZMMU), and the Muséum d'histoire naturelle, Geneva, Switzerland (MHNG).

In the description, the sequence of leg segment measurements is as follows: femur + patella + tibia + metatarsus + tarsus. All measurements are given in $\mathrm{mm}$. Scale bars in the figures correspond to $0.1 \mathrm{~mm}$. The formula of chaetotaxy means the number of dorsal spines on tibia I-IV.

The terminology of copulatory organs follows that of Merrett [1963] and Hormiga [2000].

The following abbreviations are used in the text and figures: ARP — anterior radical process; DSA distal suprategular apophysis; E - embolus; Fe femur; Mt - metatarsus; $\mathrm{R}$ - radix; S - suprategulum; Ti — tibia; TmI — position of trichobothrium on metatarsus I.

\section{Description}

$$
\text { Asthenargus adygeicus sp.n. }
$$

Figs 1-9.

HOLOTYPE OT (ZMMU), RUSSIA, Caucasus, Adygea Republic, Maikop District, $6 \mathrm{~km} \mathrm{~S}$ of Pervomayskiy, environs of "Lesnaya skazka", Polkovnitskaya balka, $44.345400^{\circ} \mathrm{N}$ $40.189467^{\circ} \mathrm{E}$, ca. $450 \mathrm{~m}$ a.s.l., pitfall traps, 1-17.X.2011, leg. Yu. Chumachenko.

PARATYPES: $2 O^{7} O^{7}$ (ZMMU), collected together with holotype; 2 우 (ZMMU), Polkovnitskaya balka, $44.345400^{\circ} \mathrm{N}$ $40.189467^{\circ} \mathrm{E}, 450 \mathrm{~m}$ a.s.1., pitfall traps, 15.IV.-2.V.2011; $2 \mathrm{O}^{\top} \mathrm{O}^{\top}$, 


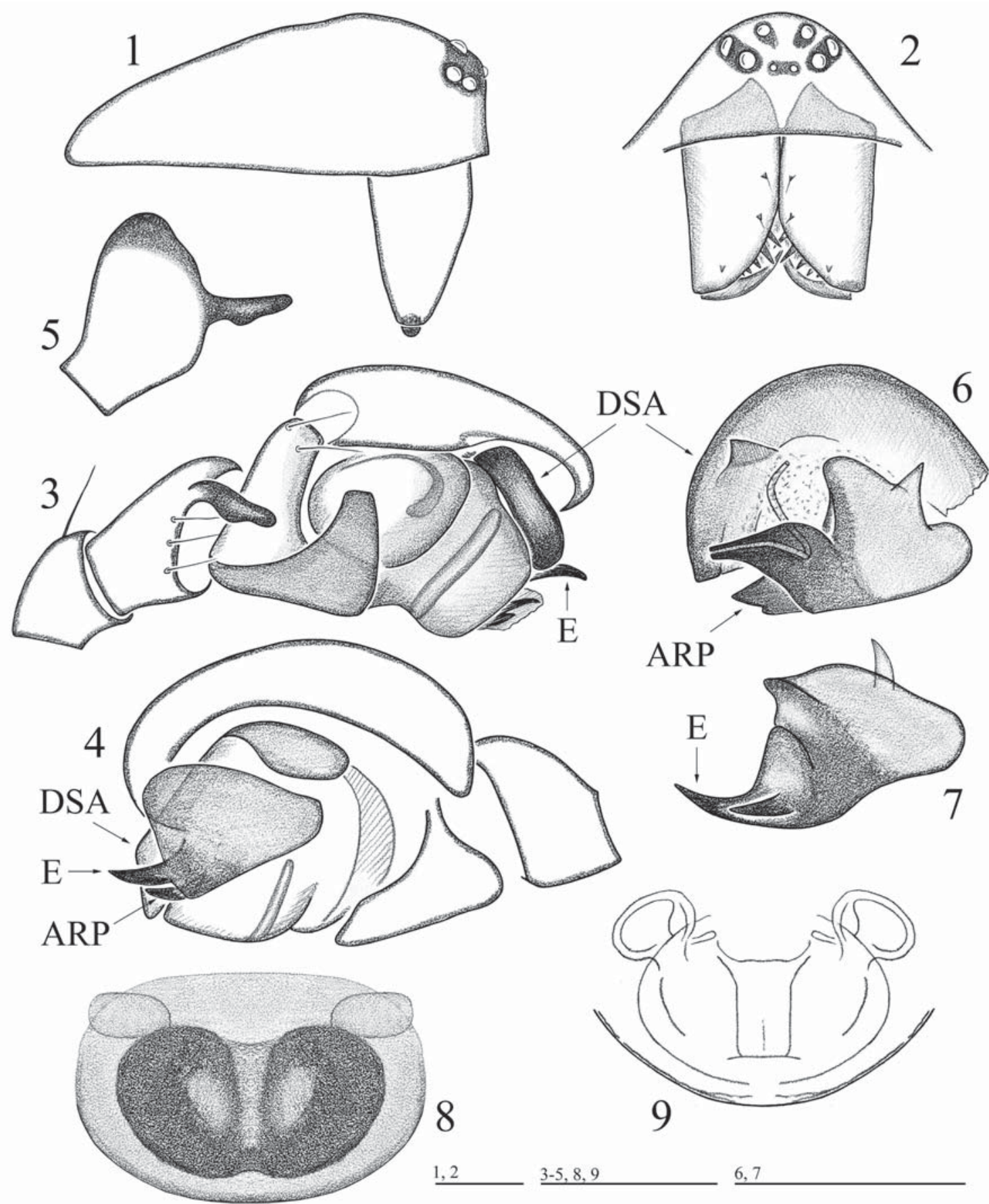

Figs 1-9. Asthenargus adygeicus sp.n., $\mathrm{O}^{7}$ and + paratypes from Polkovnitskaya balka. 1, $2-\mathrm{O}^{7}$ carapace, lateral and frontal views, respectively; 3,4 - right palp, retrolateral and prolateral views, respectively; 6 - distal suprategular apophysis and embolic division; 7 - embolic division; 8 - epigyne, ventral view; 9 - cleared epigyne, ventral view.

Pис. 1-9. Asthenargus adygeicus sp.n., $\mathrm{O}^{7}$ и 9 паратипы из Полковнической балки. 1, 2 - карапакс $0^{7}$, латерально и фронтально, соответственно; 3,4 - правая пальпа, ретролатерально и пролатерально, соответственно; 6 - дистальный отросток супратегулюма и эмболюсный отдел; 7 - эмболюсный отдел; 8 - эпигина, вид снизу; 9 - просветлённая эпигина, вид снизу.

1 o (ZMMU), Polkovnitskaya balka, Quercus \& Carpinus forest, $44.345400^{\circ} \mathrm{N} 40.189467^{\circ} \mathrm{E}$, pitfall traps, 16.III.-1.IV.2011; $7 \mathrm{O}^{7} \mathrm{O}^{\prime}$ (ZMMU), 2 O $^{7}, 1$ ㅇ (MHNG), Maikop District, Lagonaki Plateau, near Pass Azishskiy, Fagus \& Abies forest, $1800 \mathrm{~m}$ a.s.1., $44.077694^{\circ} \mathrm{N} 40.011306^{\circ} \mathrm{E}$, pitfall traps, 26.VIII.-23.IX.2013, all leg. Yu. Chumachenko.
ETYMOLOGY. The specific name refers to the terra typica; adjective.

DIAGNOSIS. The species is characterized by the absence of a mastidion, the thinner embolus and the rounded shape of the epigyne. 


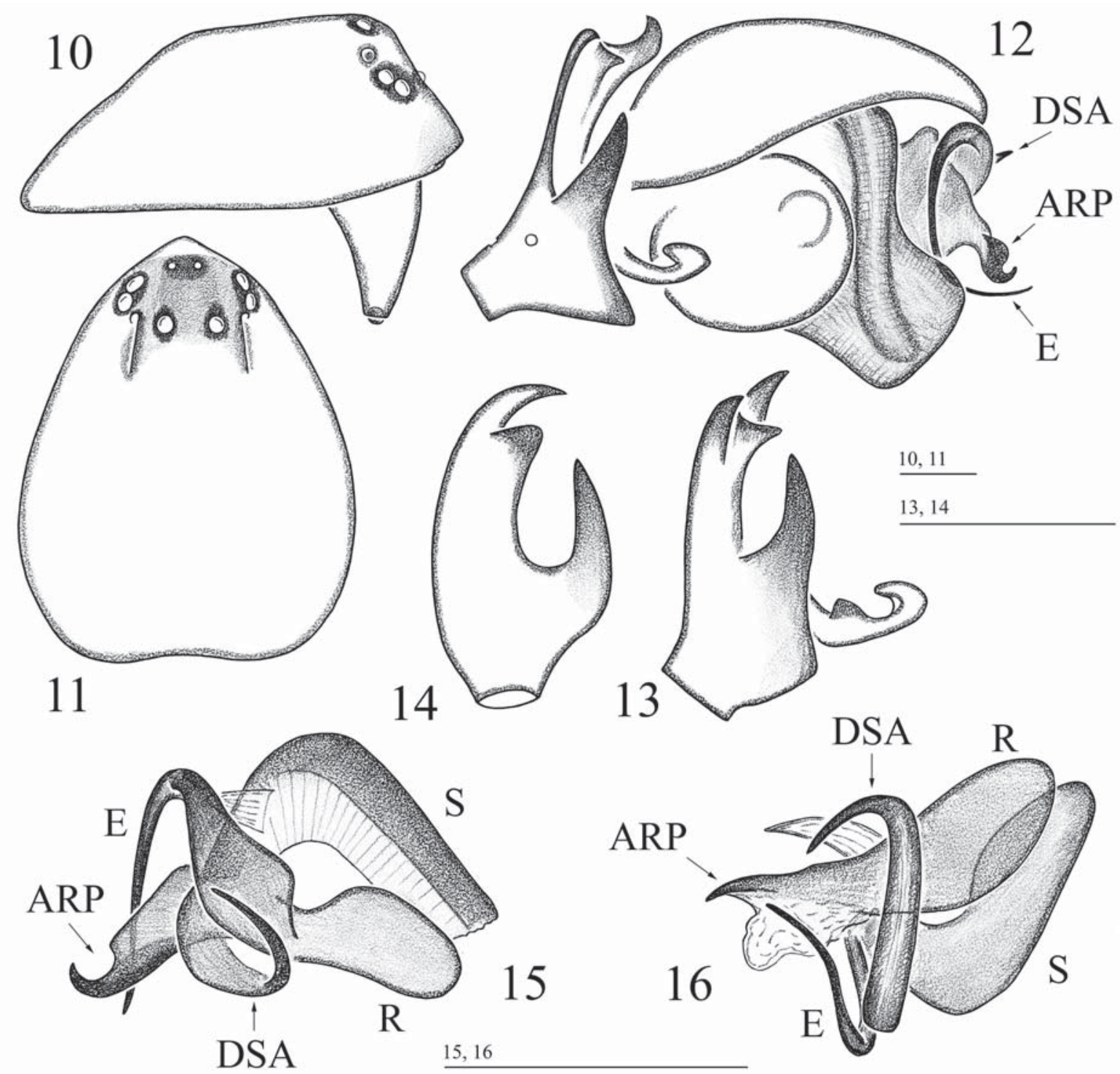

Figs 10-16. Maculoncus (?) obscurus sp.n. $0^{7}$ paratype from the Caucasian Nature Reserve. 10, 11 -carapace, lateral and dorsal views, respectively; 12 - right palp, retrolateral view; 13 - palpal tibia and paracymbium, anterolateral view; 14 — palpal tibia, dorsal view; 15, 16 - distal suprategular apophysis and embolic division, different aspects.

Рис. 10-16. Maculoncus (?) obscurus sp.n. $0^{7}$ паратип из Кавказского заповедника. 10, 11 - карапакс, вид сбоку и сверху, соответственно; 12 - правая пальпа, ретролатерально; 13 - голень пальпы и парацимбиум, вид сзади и соку; 14 - голень пальпы, вид сверху; 15, 16 - дистальный отросток супратегулюма и эмболюсный отдел, различные аспекты.

DESCRIPTION. Male paratype from Polkovnitskaya balka. Total length $0.93(0.90-1.10 ; 12$ samples measured). Carapace 0.55 long, 0.48 wide, pale brown to brown, unmodified (Fig. 1). Chelicerae 0.24 long, mastidion absent, only a small distal denticle present on frontal cheliceral face (Fig. 2). Legs pale yellow to pale brown, leg I, 1.63 long $(0.48+0.18+$ $0.40+0.31+0.26), \mathrm{IV}, 1.49(0.43+0.18+0.35+$ $0.30+0.23)$. Chaetotaxy 2.2.2.1, spines thin, weak, about as long as or a little longer than segment diameter. TmI, 0.34. Metatarsi IV without trichobothrium. Palp (Figs 3-7): tibia short, with a retrolateral, specific, dark process. Paracymbium relatively large, L- shaped. Distal suprategular apophysis relatively long, abruptly truncate apically. Radix more or less rounded, with a strong, well-sclerotized, anterior radical apophysis and a small, sharp, almost transparent apophysis in middle part of radix. Embolus short, claw-shaped. Abdomen 0.50 long, 0.30 wide, white or pale grey.

Female from Polkovnitskaya balka. Total length 1.38 (1.20-1.38; three samples measured). Carapace 0.65 long, 0.53 wide, pale brown to brown. Chelicerae 0.25 long. Legs pale yellow to pale brown, leg I, 1.66 long $(0.50+0.20+0.38+0.33+0.25)$, IV, $1.70(0.50$ $+0.18+0.43+0.35+0.24)$. Formula of chaetotaxy as in male. TmI 0.35. Metatarsi IV without trichobothri- 
um. Epigyne rounded (Figs 8, 9), with strongly sclerotized internal parts. Receptacles slightly elongated, widely apart. Abdomen 0.83 long, 0.60 wide, white or pale grey.

TAXONOMIC REMARKS. The species seems to be most similar to its Caucasian congener, A caucasicus Tanasevitch, 1987, but can easily be distinguished by the absence of a mastidion, a thinner embolus, the presence of outgrowths on the embolic division in the male, by the rounded epigyne with more strongly separated receptacles in the female.

DISTRIBUTION. Known only from the Republic of Adygea, Caucasus, Russia.

\section{Maculoncus (?) obscurus sp.n. Figs 10-16.}

HOLOTYPE $0^{7}$ (ZMMU), RUSSIA, Caucasus, Adygea Republic, Caucasian Nature Reserve, 3 road-km between Guzerip and Pasture Abago, $1000 \mathrm{~m}$ a.s.l., dead soil-covering forest with Fagus orientalis \& Abies nordmanniana, pitfall traps, 20.V.6.VI.2009, leg. Yu. Chumachenko.

PARATYPES: $3 \sigma^{\top} \sigma^{7}$ (ZMMU), $2 \sigma^{7} \sigma^{7}$ (MHNG), collected together with holotype. $1 \sigma^{\prime}$ (ZMMU), GEORGIA, Tkibuli District, $15 \mathrm{~km}$ E of Tkibuli, Mukhura, 700-800 m a.s.1., Castanea, Fagus \& Carpinus forest, litter sifting, under bark \& stones, 7 9.V.1987, leg. S. Golovatch \& K. Eskov.

ETYMOLOGY. The species name refers to the ambiguous taxonomic position of this species; adjective.

DIAGNOSIS. The new species is characterized by the peculiar shape of the palpal tibia, the very long distal suprategular apophysis and the specific shape of the embolus.

DESCRIPTION. Male holotype. Total length 1.09. Carapace 0.56 long, 0.43 wide, brown. Clypeus slightly protruded conically, sulci small, rounded, situated just near posterior median eyes (Figs 10, 11). Chelicerae 0.29 long, mastidion absent. Legs yellow, leg I, 1.33 long $(0.39+0.12+0.31+0.25+0.26)$, IV, $1.37(0.41$ $+0.12+0.35+0.26+0.23)$. Chaetotaxy 2.2.1.1, spines of tibia very small, poorly-visible. TmI, 0.33. Metatarsi IV without trichobothrium. Palp (Figs 1216): prolateral lobe of tibia with three short and small projections; retrolateral lobe sabre-shaped. Paracymbium small and narrow, with a sharp tooth in middle part. Distal suprategular apophysis very long, making a loop, its distal part narrow, darkened. Embolus thin, making a semi-loop. Radix long, wide, twisted at middle. End of anterior radical process hook-shaped, darkened. Abdomen 0.66 long, 0.43 wide, pale grey.
Female unknown.

TAXONOMIC REMARKS. The taxonomic position of Maculoncus obscurus sp.n. is unclear. According to the conformation of the embolic division, the new species seems to be most similar to representatives of Maculoncus Wunderlich, 1995, i.e., the East Mediterranean M. parvipalpus Wunderlich, 1995 and the Taiwanese $M$. orientalis Tanasevitch, 2011 (see Wunderlich, 1995; Tanasevitch, 2011, 2016). However, $M$. obscurus sp.n. differs from these formal congeners by its chaetotaxy (2.2.1.1 versus 1.1.1.1), the clearly modified palpal tibia, the strongly developed distal suprategular apophysis, as well as by the presence of sulci on the carapace. These differences allow us to place the new species in the genus Maculoncus, yet only provisionally.

DISTRIBUTION. Known from the Caucasus: Republic of Adygea, Russia; Georgia.

ACKNOWLEDGEMENTS. The authors are grateful to Sergei I. Golovatch for checking the English of an earlier draft.

\section{References}

Hormiga G. 2000. Higher level phylogenetics of erigonine spiders (Araneae, Linyphiidae, Erigoninae) // Smithsonian Contributions to Zoology. No.609. P.1-160.

Merrett P. 1963. The palpus of male spiders of the family Linyphiidae // Proceedings of the Zoological Society of London. Vol.140. P.347-467.

Tanasevitch A.V. 2011. On some linyphiid spiders from Taiwan (Araneae: Linyphiidae) // Zootaxa. Vol.3114. P.31-39.

Tanasevitch A.V. 2016. New species and new records of linyphiid spiders from Israel (Aranei: Linyphiidae) // Arthropoda Selecta. Vol.25. No.3. P.297-306.

Tanasevitch A.V., Ponomarev A.V. 2015. A new Gongylidiellum Simon, 1884 from the western Caucasus (Arachnida: Aranei: Linyphiidae) // Arthropoda Selecta. Vol.24. No.1. P.113-116.

Tanasevitch A.V., Ponomarev A.V., Chumachenko Yu.A. 2015. Notes on the spider genus Bisetifer Tanasevitch, 1987 (Aranei: Linyphiidae), with the description of a new species // Arthropoda Selecta. Vol.24. No.4. P.445-450.

Tanasevitch A.V., Ponomarev A.V., Chumachenko Yu.A. 2016. A new species of Tenuiphantes Saaristo et Tanasevitch, 1996 (Aranei: Linyphiidae) from Adygea, the Caucasus, Russia // Arthropoda Selecta. Vol. 25. No.2. P.217-218.

Wunderlich J. 1995. Zur Taxonomie europäischer Gattungen der Zwergspinnen (Arachnida: Araneae: Linyphiidae: Erigoninae) // Beiträge zur Araneologie. Bd.4. S.643-654.

Responsible editor K.G. Mikhailov 